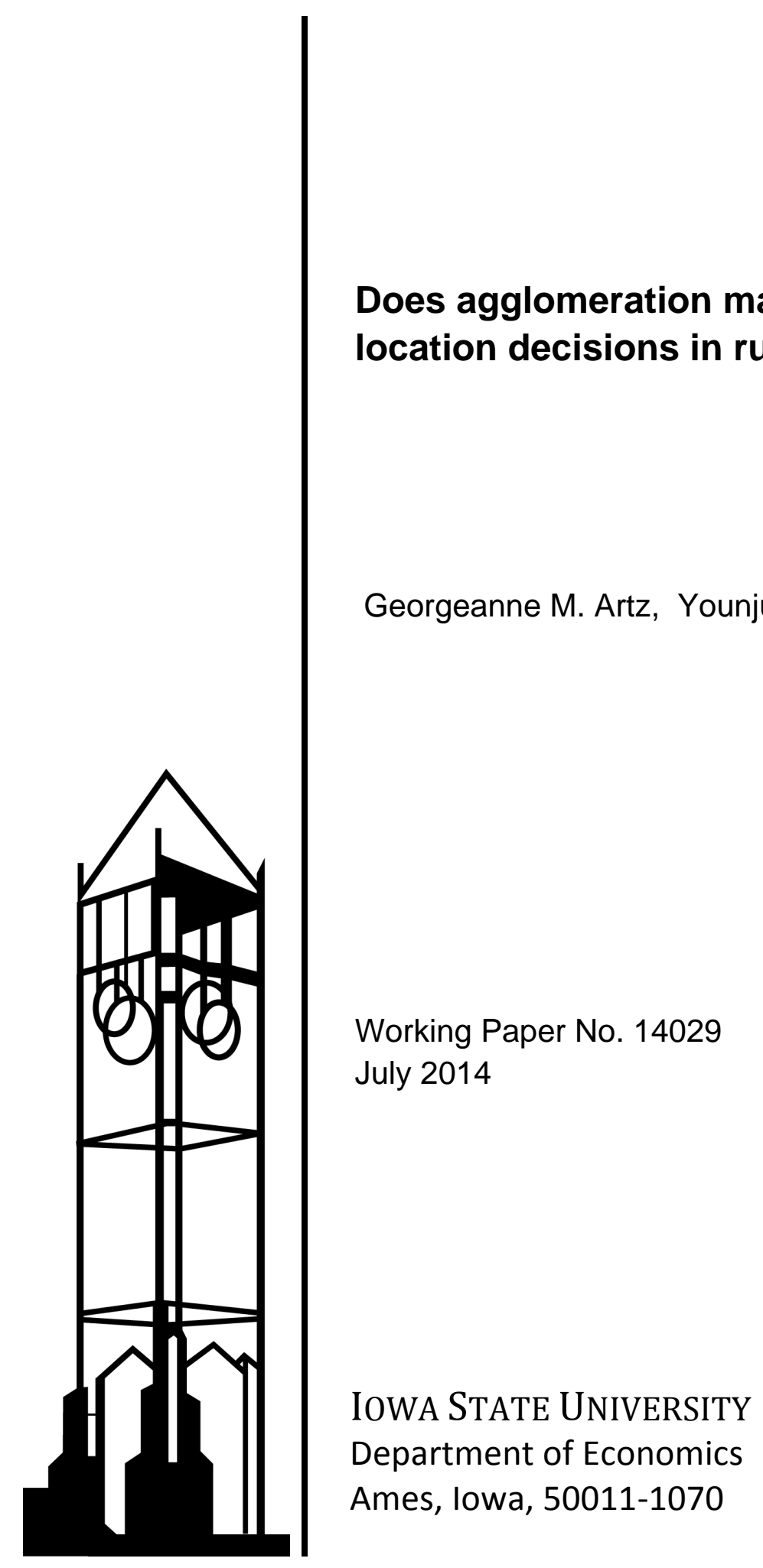

lowa State University does not discriminate on the basis of race, color, age, religion, national origin, sexual orientation, gender identity, genetic information, sex, marital status, disability, or status as a U.S. veteran. Inquiries can be directed to the Director of Equal Opportunity and Compliance, 3280 Beardshear Hall, (515) 294-7612. 


\title{
Does agglomeration matter everywhere?: new firm location decisions in rural and urban markets
}

\author{
July, 2014 \\ Georgeanne M. Artz, Younjun Kim and Peter F. Orazem
}

\begin{abstract}
We test whether commonly used measures of agglomeration economies encourage new firm entry in both urban and rural markets. Using new firm location decisions in Iowa and North Carolina, we find that measured agglomeration economies increase the probability of new firm entry in both urban and rural areas. Firms are more likely to locate in markets with an existing cluster of firms in the same industry, with greater concentrations of upstream suppliers or downstream customers, and with a larger proportion of college-educated workers in the local labor supply. Firms are less likely to enter markets with no incumbent firms in the sector or where production is concentrated in relatively few sectors. The same factors encourage both stand-alone start-ups and establishments built by multiplant firms. Commuting decisions exhibit the same pattern as new firm entry with workers commuting from low to high agglomeration markets. Because agglomeration economies are important for rural firm entry also, policies encouraging new firm entry should focus on relatively few job centers rather than encouraging new firm entry in every small town.
\end{abstract}

Key words: firm entry, specialization, local monopoly, industrial diversity, upstream and downstream firms, education, stand-alone versus expansion start-ups

JEL: M13, R11, L26

Contacts: Department of Economics, Iowa State University, Ames, IA 50014. Artz: gartz@iastate.edu, Kim: ykim@iastate.edu and Orazem: pfo@iastate.edu 


\section{Introduction}

Agglomeration economies are commonly cited as a reason for the growth of cities. ${ }^{1}$ New firms are attracted by the possibility of lower production costs or enhanced revenue streams made possible by locating close to customers or other firms. However, studies differ as to the source of these positive externalities. ${ }^{2}$ Some agglomeration economies are related to availability of or proximity to production input factors and buyers. Being close to upstream input suppliers or downstream customers lowers transportation costs and may improve information flows between producers and consumers (Jofre-Monseny et al., 2011; Ellison et al., 2010). Large concentrations of educated workers may hasten adaptation of new ideas and lower the costs of labor turnover (Shapiro, 2006; Moretti, 2004). Having a cluster of similar firms may hasten innovation and improve firm productivity because firms can learn from one another or because they can share a larger specialized labor pool (Porter, 2003). Having a highly diversified mixture of firms may improve cross-fertilization of ideas across different firms (Feldman and Audretch, 1999; Glaeser et al., 1992). Local monopoly allows firms to grow much larger which may enable them to exploit the rents from new innovation without risk that the returns will be lost to competitors (Marshall, 1920).

Most previous studies of agglomeration have focused on growth occurring in cities. By definition, rural areas lack agglomeration and so they would seem to lack these productive advantages that benefit firms in cities. Local factors related to agglomeration economies might have different signs or magnitudes of impacts between urban and rural areas. ${ }^{3}$ For

\footnotetext{
1 For reviews on agglomeration economies, see Duranton and Puga (2014), Puga (2010), Glaeser and Gottlieb (2009), and Rosenthal and Strange (2004).

2 Duranton and Puga (2004) explain agglomeration economies using three mechanisms: sharing, matching and learning. Firms can receive benefits from sharing facilities and infrastructures, input suppliers and a labor pool. Firms and workers, and buyers and sellers can have better matching in a larger market. New technologies and business practices can be developed and diffused faster in a larger market. The intensity and composition of production activity influences the mechanisms.

${ }^{3}$ Rural firms have different characteristics compared to urban firms. See Renski and Wallace (2012) for simple rural-urban comparison of new firms. Differences are found in terms of industries that new firms enter, employment growth within four years after their opening, types of their major clients and education level of
} 
example, proximity to input suppliers might be more important in rural areas than in urban areas because of the costs of transporting raw materials relative to finished goods (Kilkenny, 1998). Rural firms may be less concerned with the availability of educated workers if they are more concentrated in less-skilled and less technology-oriented industries such as retail or personal services compared to urban firms (Renski and Wallace, 2008).

We use a data set on the location decisions of new firms in Iowa and North Carolina to examine how local agglomeration economies influence firm start-ups, and whether agglomeration economies have different effects on the location choices of rural and urban start-ups. If agglomeration generates productivity or cost advantages to firms in a local market, they should have the greatest influence on firms at the time of entry. Because a new venture can open anywhere in principle, firms will assess the value of local agglomeration and other market factors as they decide where to locate. It is costly to relocate once the entry occurs, and so aggregate growth measures that are heavily weighted toward incumbent firms such as local employment or local output growth will reflect past levels of market factors that may no longer apply.

Another advantage to our use of new firm entry as a measure of market response to agglomeration is that local market factors are pre-determined and outside the control of nascent firms. This reduces the problem of reverse causality between agglomeration measures and more commonly used measures of economic performance such as growth in the numbers of firms or workers. For example, there may be a positive correlation between the number of firms and the proportion of college-educated workers due to the mobility of educated workers rather than spillover productivity effects from a concentration of educated workers. However, the entry of one new firm will not alter the concentration of educated 
workers in the labor market, but a new firm will enter a market with more college-educated workers if the firm can benefit from the spillover productivity benefits. If educated workers do not have spillover effects, new firms would not react to the current distribution of educated workers. ${ }^{4}$

We investigate the effect of six measures of agglomeration on firm incentives to locate in an urban or rural market: the number of incumbent firms in the industry; the absence of any incumbent firms in the industry; the degree of industrial diversity; proximity to upstream and downstream firms; and the proportion of college educated in the adult population. Our results indicate that the same agglomeration measures that have been associated with urban economic growth are important for rural firm entry as well. The pattern holds for both all firms and manufacturing firms, and for both stand-alone ventures and multi-plant firms looking to expand into new markets. The pattern holds for rural firm entry regardless of whether the area is adjacent to or distant from an urban area. Commuters are attracted to the same agglomeration factors that attract new firm start-ups. As a result, even in rural areas, production would be predicted to concentrate increasingly in relatively few locations with workers commuting from the surrounding communities that lack the ability to offer sufficient agglomeration economies.

This paper is organized as follows. In the next section, we review the few studies using a rural-urban comparison to examine agglomeration economies, and discuss different theories in local agglomeration economies. In Sections 3 and 4, we explain our empirical strategy and define our agglomeration measures. In Sections 5 and 6, we provide estimation results and conduct robustness checks of our results using an employment-based analysis. Lastly, we test the role of agglomeration economies in commuting and discuss the policy

\footnotetext{
4 Jofre-Monseny et al. (2011) and Rosenthal and Strange (2003) advanced similar arguments to justify their focus on new firm location decisions.
} 
implications of our results.

\section{Literature Review}

While scholars generally agree on the existence of productive spillovers in cities, they disagree on which local attributes are critical to the existence of the externalities. We focus on six local attributes that have figured prominently in the literature: clusters of similar firms, the ability to exert monopoly power, industrial diversity, proximity to upstream and downstream firms and concentrations of educated workers.

Marshall (1920) argued that there is an advantage for firms in the same industry to locate near one another because workers and firms learn from each other and the learning helps them develop new ideas. ${ }^{5}$ Specialization in a given type of production allows firms to share in a pool of workers with similar skills and saves transportation cost of materials. In addition, new firms will enter as upstream suppliers of inputs for the cluster of firms in the industry.

Marshall also argued that larger firms have advantages over a larger number of small firms because of returns to scale in innovation and because firms can better internalize the returns to their innovation. ${ }^{6} \quad$ A single large firm might be most able to capitalize on their innovations, although that would presumably limit the spillovers to other firms. ${ }^{7}$ Schumpeter

\footnotetext{
5 "When an industry has thus chosen a locality for itself, it is likely to stay there long: so great are the advantages which people following the same skilled trade get from near neighbourhood to one another. The mysteries of the trade become no mysteries; but are as it were in the air, and children learn many of them unconsciously. Good work is rightly appreciated, inventions and improvements in machinery, in processes and the general organization of the business have their merits promptly discussed: if one man starts a new idea, it is taken up by others and combined with suggestions of their own; and thus it becomes the source of further new ideas. And presently subsidiary trades grow up in the neighbourhood, supplying it with implements and materials, organizing its traffic, and in many ways conducing to the economy of its material." (Marshall, 1920, p.271)

6 As an example of how larger firms have greater innovation capacity, Marshall states that "[in the pottery trade, a small manufacturer] cannot afford even to make experiments with new patterns and designs except in a very tentative way." (Marshall, 1920, p.281)

7 “[A multitude of comparatively small rival producers] could not afford to spend as much on improving methods of production and the machinery used in it, as a single large firm which knew that it was certain itself
} 
(1942) extended this line of reasoning and argued that firms have no incentive to enter perfectly competitive markets because they will not be able to exploit the full advantages of their innovations. ${ }^{8}$

Porter (1990) followed Marshall in arguing that clusters of similar specialized firms increases the productivity of all the firms through knowledge spillovers. However, he expanded on Marshall to include other firms in the industry as well as upstream suppliers and downstream customers in the cluster. Interaction and information flows across firms within a cluster promote technological innovation. ${ }^{9}$ Helsley and Strange (2002) also support importance of various input suppliers. In contrast to Marshall (1920) and Schumpeter (1942), Porter argued that competition helps technological innovation because competitive pressure makes firms adopt and develop new technology to survive.

Jacobs (1969) believed that technology innovation came from industrial diversity rather than industrial specialization. She suggested that seemingly unrelated ideas can provide breakthroughs to achieve technological innovation. ${ }^{10}$ Following Jacobs, Lucas (1988) also emphasized the role of interactions between people as the rationale for cities. However, Lucas emphasized that it was concentrations of skilled people that were particularly important for the generation of a human capital externality. Productive interactions between educated people make each of them more productive than they would be in isolation. These externalities counteract the natural tendency of cities to fly apart

to reap the whole benefit of any advance it made." (Marshall, 1920, p.484) Arrow (1962) and Romer (1986) also view competition as bad for innovation because innovators cannot be compensated for the spillovers from their innovations fully.

8 "But perfectly free entry into a new field may make it impossible to enter it at all. The introduction of new methods of production and new commodities is hardly conceivable with perfect — and perfectly promptcompetition from the start." (Schumpeter, 1942, pp.104-105)

9 "Once a cluster forms, the whole group of industries becomes mutually supporting. Benefits flow forward, backward, and horizontally. [...] Interconnections within the cluster, often unanticipated, lead to the perception of new ways of competing and entirely new opportunities." (Porter, 1990, p.151)

10 "The greater the sheer numbers and varieties of divisions of labor already achieved in an economy, the greater the economy's inherent capacity for adding still more kinds of goods and services." (Jacobs, 1969, p.57) 
because concentrations of economic activity bid up the costs of land, labor and other factors of production.

The empirical research investigating the effects of agglomeration economies is mixed. The earliest study to examine the relative strength of these hypotheses empirically was Glaeser et al. (1992). They found that industrial diversity and local competition improve employment growth in cities. Rosenthal and Strange (2003) also found positive impacts of diversity and local competition on new firm entry. In contrast to the employment-based analysis in Glaeser et al., Cingano and Schivardi (2004) found that firm-level productivity was improved by specialization, but not by diversity and local competition. ${ }^{11}$ Other studies have found that industrial clusters (specialization) foster more entrepreneurship and lead to higher employment growth (Delgado et al., 2010; Porter, 2003) and higher wages (Wheaton and Lewis, 2002). However, De Blasio and Addario (2005) did not find higher wages in clusters and Duranton (2011) found only modest sized cluster effects. Henderson et al. (1995) found that specialization is important for mature manufacturing industries while industrial diversity is important for high-tech manufacturing industries.

In line with Lucas (1988), Moretti (2004) found empirical evidence that a concentration of college graduates improves productivity of all firms in the market. The external productivity spillovers are larger when the concentration of educated workers is largest in technologically similar firms, in firms that cite similar patents, and in firms that are upstream suppliers or downstream customers. Winters (2013) and Shapiro (2006) also found that the probability of being employed and local employment growth were higher in areas with relatively large concentrations of skilled workers, respectively. Glaeser and Mare (2001) found that wages grow faster in cities, presumably due to faster human capital accumulation. As for upstream and downstream links, Jofre-Monseny et al. (2011), Ellison

11 Their replication of the employment analysis was consistent with Glaeser et al. 
et al. (2010) and Glaeser and Kerr (2009) found evidence supporting the importance of upstream and downstream linkages. The estimated magnitude of agglomeration effects on productivity varies widely across studies depending on the context (Melo et al., 2009).

While the bulk of the research on agglomeration effects has focused on cities, there are a number of existing studies that highlight the importance of agglomeration economies in rural areas. Given that rural firms have different characteristics than urban firms (Renski and Wallace, 2012; Renski, 2008; Yu et al., 2010), they may react to local agglomeration factors differently or not at all. To our knowledge, Gabe (2003) is the only study to compare rural and urban agglomeration economies, although he only studied responses to local specialization rather than a menu of agglomeration measures.

Rural places can experience agglomeration economies in two ways. Because the benefits of agglomeration attenuate with distance (Rosenthal and Strange, 2003 and 2008), remote rural communities would have to foster agglomeration locally. While challenging in a small local economy, it is possible for small remote towns to develop sufficient intensity in a sector to affect local economic performance. Research has shown that rural industry clusters increase employment (Henry and Drabenstott, 1996) and local wages (Gibbs and Bernat, 1997). Barkley, Henry and Kim (1999) showed that larger firm clustsers in an industry lead to faster employment growth for growing industries in non-metropolitan areas. Gabe (2005) found that greater specialization in a rural firm's own industry increased its capital investment, but the effect is relatively modest.

On the other hand, agglomeration economies can spill over to surrounding areas so that rural areas can access urban agglomeration benefits through commuting (Partridge at al., 2010). For this reason, positive impacts of urban agglomeration economies are found in rural areas within a commuting distance of cities (Partridge et al., 2007 and 2008; Barkley et al., 1996). In principle, urban agglomeration economies can have positive or negative 
impacts on rural areas depending on commuting and migration flows, and the relocation of firms (Renkow and Hoover, 2000; Wu and Gopinath, 2008). For example, if urban residents move to adjacent rural towns and commute to urban areas, rural towns may experience spread: positive economic impacts from urban agglomeration economies. If instead of commuting, rural residents move to the urban center, agglomeration economies would result in backwash, causing rural communities to decline.

Establishment location decisions may respond differently to local agglomeration if the plant is part of a multi-plant firm rather than a stand-alone firm. For example, a multiplant firm may be less sensitive to local upstream suppliers or downstream customers if the plant is part of an integrated but geographically dispersed supply chain. Previous research has found that stand-alone start-ups are more sensitive to local agglomeration factors such as industrial diversity (Glaeser et al., 2010), sectoral firm clusters (Henderson, 2003) and the available supply of educated workers (Barkley and Keith, 1991). None of these studies compared the impact of agglomeration economies on stand-alone versus expansion start-ups across rural and urban locations.

\section{Model}

We want to examine how agglomeration economies affect firm decisions on where to locate. To that end, we sketch an empirically tractable model in which an entrepreneur decides where to locate a new establishment, given information on the nature of the business and its anticipated profitability across all possible locations. To begin, assume that the firm has $C$ possible markets in which to locate $(c=1, \ldots, C)$. We assume these markets follow county boundaries. Each market has up to $K$ sectors $(k=1, \ldots, K)$. Note that the absence of a sector represents a potential entry opportunity for a monopolist.

Price-taking firms maximize their profit in two stages. In the first stage, firm $i$ in sector $k$ computes its expected profit in each market $c$. Given those computations, the firm 
chooses the location with maximum profit $\left(\pi_{i k}^{*}\right)$ in the second stage. ${ }^{12}$ Expected profit is given by:

$$
\pi_{i k}^{*} \equiv \operatorname{Max}_{c} \pi\left(m_{k c}, z_{c}, p_{k}, w_{c}, r_{c}\right)
$$

The vector of local agglomeration measures, $m_{k c}$, affects expected profit in county $c$ by altering anticipated production costs. The vector of control variables, $Z_{c}$, includes local demand shifters and dummy variables for county characteristics and state. The former influences production quantity and firm profit. The latter reflects common unobservable effects for all firm entrants in a county group and the state in which county $c$ is located. Firm profit $(\pi)$ increases in the sector-specific market price, $p_{k}$, which we assume is equal across areas, and decreases in local wages $\left(w_{c}\right)$ and capital rents $\left(r_{c}\right)$.

We define the vector of local agglomeration measures $\left(m_{k c}\right)$ to include measures based on the conceptual and empirical studies reviewed in the previous section:

$$
m_{k c} \equiv\left[C L U_{k c}, M O N_{k c}, C O N_{c}, U P_{k c}, D O W N_{k c}, E D U_{c}\right]
$$

The variables represent cluster specialization in the sector $\left(C L U_{k c}\right)$; the absence of any firms in the sector which would provide a local monopoly opportunity $\left(M O N_{k c}\right)$; local industrial concentration $\left(C O N_{c}\right)$; local access to upstream suppliers $\left(U P_{k c}\right)$ and downstream customers $\left(D O W N_{k c}\right)$ of firms in the sector; and the local availability of college educated workers $\left(E D U_{c}\right)$

The first attribute corresponds to Marshall's (1920) and Porter's (1990) emphasis that a concentration of firms specialized in a single industry improves productivity through shared knowledge and a shared pool of specialized labor. The second reflects the presumption that a single firm can internalize the local knowledge and innovate at a lower cost than can a large

\footnotetext{
12 Our assumption of expected profit maximization may not be true. First, people may not compute expected profit correctly, and second, they may be maximizing expected utility, placing a big weight on the location at the expense of the profitability of the firm. However, the reduced form specification we use tests whether the theorized relationships between agglomeration and profit carry over to firm location choices. Our results are consistent with these well-established theories.
} 
number of small firms, points emphasized by Marshall (1920), Arrow (1962), Romer (1986) and Schumpeter (1942). ${ }^{13}$ The third reflects Jacobs (1969) emphasis on a diverse mix of firms in contrast to the preference for specialization emphasized by Marshall and Porter. The fourth and fifth reflect upstream and downstream clusters that are mentioned prominently in Marshall, Porter, and Ellison et al. (2010). The last is related to Lucas's (1988) emphasis on shared pools of high quality labor.

We define the vector of control variables $\left(z_{c}\right)$ :

$$
Z_{c} \equiv\left[I N C_{c}, U R B_{c}, R_{-} A D J_{c}, R_{-} B I G_{c}, N C_{c}\right]
$$

where $I N C_{c}$ is median household income in county $c$ which indexes local demand for goods and services. We also use a series of dummy variables to indicate county size and state. Using the Rural-Urban Continuum Codes (RUCC) from Economic Research Service, U.S. Department of Agriculture, $U R B_{c}$ indicates the county is considered urban or metropolitan $($ RUCC $=0-3) ; R \_A D J_{c}$ indicates the county is rural and adjacent to a metropolitan area $(\mathrm{RUCC}=4,6,8) ; R_{-} B I G_{c}$ indicates the county is rural and has an urban population of 2,500 or more $(\mathrm{RUCC}=4-7)$; and $N C_{c}$ indicates the county is located in North Carolina. $R \_A D J_{c}$ addresses the access of rural counties to urban agglomeration economies because agglomeration economies attenuate with distance (Rosenthal and Strange, 2003 and 2008).

We assume a spatial equilibrium where wages and capital costs are adjusted to agglomeration measures $\left(m_{k c}\right)$ affecting firm productivity (Rosen, 1979; Roback, 1982). If markets are competitive, firms will expect to make zero economic profits in the long run in all areas. If the agglomeration level $m_{k c}$ changes over time, lower production costs and increase profits in sector $k$ and county $c$, market $k c$ will attract additional entry relative to other markets. Entering firms will bid up the input prices for labor and capital until

\footnotetext{
13 Alternatively, the local monopoly variable may represent negative signal to new firms. In other words, no incumbent firms in the industry in the county may mean that the industry does not have advantage in the county.
} 
expected profits from additional entry are reduced back to zero. That suggests that in the long run equilibrium, wages and rents will be represented as functions of $m_{k c}$. As Shapiro (2006) shows, both local wages and local rents respond to local amenities and access to productive externalities.

We assume that the firm makes its decision based on the information available on market conditions in the year just prior to entry, so that expected profits are a function of agglomeration measures in year $t-1$. The linear approximation to the reduced-form profit function of firm $i$ in industry $k$, county $c$ and year $t$ is given by:

$$
\pi_{i k c t} \equiv m_{k c t-1}^{\prime} \gamma_{m}+z_{k c t-1}^{\prime} \gamma_{z}+\varepsilon_{i}+\varepsilon_{k}+\varepsilon_{t}+u_{i k c t}
$$

where the error terms $\varepsilon_{i}$ and $\varepsilon_{k}$ reflect common unobserved elements that influence profit for firm $i$ across all locations and industry $k$ profits across all firms. The temporal shock, $\varepsilon_{t}$, is a common shock to all firm entrants across all locations in year $t$. The last term $u_{i k c t}$ is a random shock to profits for firm $i$ in county $c$ that is assumed to be uncorrelated with all other factors. ${ }^{14}$

Each new firm entrant in year $t$ chooses one of the potential $C$ areas to enter, based on anticipated profitability. We define the dichotomous variable $E_{i k c t}=1$ if the firm opts to enter area $c$ in year $t$ and $E_{i k c t}=0$ otherwise. $E_{i k c t}=1$ if $\pi_{i k c t}-\pi_{i k c^{\prime} t} \geq 0 \forall c^{\prime} \neq c$. From the specification for profit (4), we have

$E_{i k c t}=1$ if $\left(m_{k c t-1}^{\prime}-m_{k c \prime t-1}^{\prime}\right) \gamma_{m}+\left(z_{k c t-1}^{\prime}-z_{k c \prime t-1}^{\prime}\right) \gamma_{z}>\zeta_{i k c t} \forall c^{\prime} \neq c$

where $\zeta_{i k c t} \equiv u_{i k c^{\prime} t}-u_{i k c t}$. Note that the common firm-, sector-, and time-specific economic shocks $\varepsilon_{i}, \varepsilon_{k}$, and $\varepsilon_{t}$ are differenced away because they do not affect relative

\footnotetext{
14 Our empirical approach has a possible identification issue from unobservable time-varying location-specific factors. For example, local government incentives might encourage firms in the same industry to be concentrated in one location. In this case, our specialization variable would be biased. We test this issue using different years (2003-2004) of new firm entry. We find consistent estimation results, which suggests that our main results are robust to unobservable time-varying location-specific factors. Estimates and elasticities are available upon request.
} 
profitability across markets. That leaves the pure random error term, $u_{i k c t}$ which we assume follows the type- 1 extreme distribution. We estimate (5) using the conditional logit estimator. $^{15}$

\section{Data}

In our application, firms are selecting from $C=199$ possible county locations because Iowa has 99 counties and North Carolina has 100. Our sample is commercial establishments that entered a county in Iowa and North Carolina over three years (2000-2002). We chose the sample years to align with the availability of Census data. We restrict the sample to firms with a clear profit motive, excluding non-profit organizations, government agencies and firms with a public service emphasis such as museums or historical sites. We also remove firms in agriculture and mining. These firms cannot move freely across locations as their entry decision is affected by site-specific land or resource availability. ${ }^{16}$ Our sample has 191,191 establishments; $68 \%$ of them are urban start-ups.

Establishment attributes such as location, industry and ownership are obtained from the National Establishment Time Series (NETS). ${ }^{17}$ The database provides information on the universe of all establishments that opened for business in Iowa and North Carolina in 2000-2002. The database also includes DUNS (Data Universal Numbering System) numbers of establishments and of their headquarters or parent companies. If an own DUNS number is the same as that of a headquarters or a parent company, the establishment is

\footnotetext{
15 We used STATA command "multin" in a package named "groupcl" to estimate the grouped conditional logit. See Guimaraes and Lindrooth (2007) for information on the estimator. (http://www.stata.com/meeting/5nasug/NASUG Guimaraes.pdf, accessed on June 19, 2014)

16 The following industries are excluded: Agriculture (2-digit NAICS: 11), Mining (22), Postal Service (3-digit NAICS 491), Monetary Authorities-Central Bank (521), Nursing and Residential Care Facilities (623), Social Assistance (624), Museums, Historical Sites, and Similar Institutions (712), Religious, Grant-making, Civic, Professional and Similar Organizations (813), Private Households (814), and Public Administration (92).

17 See Kunkle (2011) for advantages of NETS database compared to public data such as Quarterly Census of Employment and Wages (QCEW). (http://exceptionalgrowth.org/insights/NETSvsES-202.pdf, accessed on July.2.2014). Differently from public data based on unemployment insurance filing, NETS data include very small establishments such as sole-proprietors. Excluding establishments having less than 3 employees does not change our main findings. Estimates and elasticities are available upon request.
} 
considered a "stand-alone start-up."18 Otherwise, it is considered an "expansion start-up." Urban (rural) expansion start-ups are about $8 \%(6 \%)$ of urban (rural) start-ups in the sample period. We use 3-digit and 4-digit North American Industry Classification System (NAICS) codes used in 1997 Standard Use Table from the Bureau of Economic Analysis to define industries. The total number of industries is $K=112$.

Our agglomeration measures include four that are industry-location-specific $\left(C L U_{k c}\right.$, $M O N_{k c}, U P_{k c}$ and $\left.D O W N_{k c}\right)$ and two that are location-specific $\left(C O N_{c}\right.$ and $\left.E D U_{c}\right)$. Cluster specialization $\left(C L U_{k c}\right)$ is measured as the relative size of the proportion of establishments in industry $k$ in county $c$ to the proportion of establishments in industry $k$ in Iowa and North Carolina: ${ }^{19}$

$C L U_{k c}=\frac{\text { Establishments in } k, c}{\text { All establishments in c }} / \frac{\text { Establishments in } k \text { in Iowa and North Carolina }}{\text { All establishments in Iowa and North Carolina }}$

The local monopoly index $\left(M O N_{k c}\right)$ takes a value of 1 if county $c$ has no incumbent firm in industry $k$, and 0 otherwise. Access to upstream $\left(U P_{k c}\right)$ or downstream $\left(D O W N_{k c}\right)$ firms measures the relative availability of suppliers and customers in industry $k$ in county $c$.

These measures are constructed with data on purchases and sales by industry from the 1997 Standard Use Table, Bureau of Economic Analysis.

$U P_{k c} \equiv \sum_{s} \frac{N_{s c}}{N_{S}} \cdot \frac{\text { Input }_{s \rightarrow k}}{\text { Input }_{k}} \cdot 100 \forall s \neq k$

where $N_{s c}$ is the number of establishments in an upstream industry $s$ in county $c$, and $N_{s}$ is the number of establishments in industry $s$ in Iowa and North Carolina. The second term is the proportion of input purchases made by firms in industry $k$ from industry s.

Similarly, the proximity to downstream firms is

$\operatorname{DOWN}_{k c} \equiv \sum_{s} \frac{N_{s c}}{N_{s}} \cdot \frac{\text { output }_{k \rightarrow s}}{\text { output }_{k}} \cdot 100 \forall s \neq k$

18 According to personal communication with Walls \& Associates who compile the NETS data, the criterion holds except in rare cases.

19 This is also known as a location quotient. 
where $N_{s c}$ is the number of establishments in an downstream industry $s$ in county $c$, and $N_{s}$ is the number of establishments in industry $s$ in Iowa and North Carolina. The second term is the proportion of output purchases made by firms in industry $s$ from industry $k$.

Industrial concentration $\left(C O N_{c}\right)$ is constructed using wage bill data obtained from the Quarterly Census of Employment, Bureau of Labor Statistics. The data set has ten broad industry categories. Industrial concentration is measured by a Herfindahl- Hirschman Index computed as the sum of squared wage bill shares of industries in a county. It ranges in values from 0 to 1 , where values closer to one indicate greater industrial concentration. ${ }^{20}$ The human capital concentration $(E D U c)$ is measured by the proportion of residents over age 25 with at least a two-year college degree in county $c$. The local demand shifter $\left(I N C_{c}\right)$ is measured by median household income in county $c$. Our education and income measures were compiled from the 2000 Census.

Summary statistics on the agglomeration measures are reported in Table 1. Levels of agglomeration differ significantly between rural and urban counties. Rural counties are twice as likely to have a monopoly opportunity in a sector. Urban counties have much greater density of upstream suppliers and downstream customers. Rural counties are more concentrated in relatively few industries and have lower proportions of college educated workers.

\section{Results}

The estimation results for new firm entry (equation (5) are reported in Table 2. The first three columns show the estimates for all industries. Column (1) provides estimates for all firms. Column (2) reports the rural-urban comparison of agglomeration economies using interaction terms between urban counties $\left(U R B_{c}\right)$ and agglomeration measures. Column (3)

\footnotetext{
${ }^{20}$ Industrial concentration based on output shares would be the most appropriate. Due to data availability, we use wage bill shares instead of output shares.
} 
tests whether the effects of agglomeration economies differ for rural counties depending on the adjacency to urban counties $\left(R \_A D J_{c}\right)$. We report only estimates for the six agglomeration measures and their interaction terms. New firms are more likely to enter markets with existing firm clusters in the same industry and with better access to upstream and downstream firms and to educated workers. The opportunity for local monopoly lowers the probability of firm entry, as does greater industrial concentration. The direction of the effects of the agglomeration measures are consistent across rural and urban counties, although the magnitudes are differ (columns (2) and (3)). In columns (4) to (6), we replicate the analysis limiting the sample to manufacturing firms in order to compare our findings with other studies that focused on manufacturing ${ }^{21}$. The results for manufacturing entrants are consistent with the overall sample.

We gain additional insights by converting these estimates into elasticities to show more clearly the relative magnitudes of the effects across urban, rural adjacent, and remote rural counties. Even though there are significant differences in magnitudes of effects across urban and rural markets, the differences are rarely economically important. Aggregation measures matter in both markets and they matter similarly. In fact, the only large difference is that rural firm entry is much more sensitive to the presence of upstream suppliers, and this is true for both adjacent and remote rural counties. The other somewhat large difference is that the presence of a monopoly opportunity in the sector reduces the probability of firm entry more in urban than in rural markets. Presumably, the lack of any incumbents in a sector has more information in larger markets because the presence of monopoly opportunities is less common than in smaller markets. It appears that monopoly opportunities are not attractive because they signal a lack of comparative advantage for the

\footnotetext{
21 When we limit the sample to manufacturing firms, we exclude three counties from the choice set because they had no manufacturing entrants during the sample period, $C=196$.
} 
sector in that location. ${ }^{22}$ These conclusions carry over to manufacturing firms as well: agglomeration economies have similar effects on new firm entry in urban markets, their adjacent rural neighbors, and their more remote rural counties.

Among the agglomeration measures, new firm entry is most responsive to access to upstream firms, particularly in rural markets. Proximity to downstream customers also has a significant but smaller positive influence on new firm entry and again the effect is larger in rural markets. Our finding that firms are attracted by close proximity to upstream suppliers and downstream customers was first suggested by Marshall and is consistent with more recent conclusions regarding urban economic growth advanced by Helsley and Strange (2002), Glaeser and Kerr (2009), and Ellison et al. (2010) for urban markets. Skilled labor $\left(E D U_{c}\right)$ has the second largest positive impact on firm entry overall, and is the most important factor for manufacturing firms, a result consistent with the models of Romer (1986) and Lucas (1988), and with empirical findings reported by Moretti (2004). Consistent with Porter, clusters of local firms in the same industry attract start-ups, while the chance for local monopoly power does not attract firms. Consistent with Jacobs firms are attracted by a more diverse mix of firms. However, the presence of a monopoly deters entry, suggesting that the benefits from captured rents from innovation proposed by Marshall (1920), Arrow (1962), Romer (1986) and Schumpeter (1942) are outweighed by other costs associated with monopoly. $^{23}$

One implication of our findings is that local agglomeration continually adds to the

\footnotetext{
22 The proportional change in new firm entry probability for local monopoly is calculated for each observation and averaged across all observations. For each observation, that is calculated as follows: $\frac{P\left(E_{i k c}=1 \mid M O N_{k c}=1\right)-P\left(E_{i k c}=1 \mid M O N_{k c}=0\right)}{P\left(E_{i k c}=1 \mid M O N_{k c}=\text { status quo }\right)}$ where $P\left(E_{i k c}=1 \mid M O N_{k c}=1\right)$ is probability that firm $i$ in industry $k$ chooses county $c$ when there is no incumbent firm in that industry-county. $P\left(E_{i k c}=1 \mid M O N_{k c}=\right.$ status quo $)$ is choice probability when local monopoly is the same as the status quo.

23 We might get different answers if we were focusing on technology or R\&D intensive sectors, but most firms in our study will not be producing new products, developing unique production processes, or creating intellectual property.
} 
number of firms entering a market. As a result, places with more concentrated activities will continually attract the greatest share of new firms while places that lack these agglomeration advantages will attract few new entrants. This growth pattern results in a persistent hierarchy of city size as described in central place theory (Christaller, 1933).

Next, we test whether stand-alone start-ups are attracted by different agglomeration factors than expansion start-ups. These results are reported in Table 4. The first three columns show the estimates for expansion start-ups; the next three columns show the estimates for stand-alone start-ups. The estimated impacts of agglomeration measures on stand-alone start-ups and on expansion start-ups are consistent between urban and rural areas. The one exception is that industrial concentration $\left(C O N_{c}\right)$ does not appear to matter for expansion start-ups in rural areas, but does matter in urban areas. Panel (b) in Table 3 reports the elasticities for each firm type. Measured agglomeration effects on new firm entry are similar for expansion and stand-alone start-ups in urban, rural adjacent and remote rural counties.

Our finding that agglomeration measures have similar impacts on firm entry in rural counties adjacent to or remote from a metropolitan area may seem surprising in that adjacency to urban areas has been found to be critical in the rural development literature. ${ }^{24}$ The explanation is that agglomeration matters everywhere, but agglomeration is not present everywhere. Areas adjacent to metropolitan areas are more agglomerated than more remote rural areas and that explains their growth advantage. Proximity to an urban center undoubtedly has advantages for growth (Partridge et al., 2008) which leads to the accumulation of agglomeration measures in adjacent counties that induce additional growth.

\section{Local agglomeration measures and urban and rural growth using aggregate data}

\footnotetext{
${ }^{24}$ For extensive discussion on rural-urban interdependency for rural development, see Castle et al. (2011), Olfert and Partridge (2010), Irwin et al. (2009) and Partridge et al. (2008).
} 
As a robustness check, we examine the impact of county-level agglomeration measures on employment growth. We measure our agglomeration factors in the year 2000 and test how these factors affect local county-by-industry employment 10 years later, in 2010 . The unit of observation is the industry-county pair. We have 21,890 industry-county pairs across the two states. ${ }^{25}$ Due to many industry-county pairs having no positive local industry employment in 2000, our dependent variable is a dummy variable which has a value of 1 if employment in the industry-county pair increased between 2000 and 2010, and 0 otherwise. We estimate a binary logit model with the same set of explanatory variables as in our previous analysis. Hence, this is a net employment growth measure where employment growth can occur from both new and incumbent firms.

We find that the agglomeration measures have similar signs and magnitudes of elasticities between urban and rural areas and regardless of the adjacency to urban areas, which is consistent with our previous analysis. As shown in column 2 of Table 5, the estimated coefficients have the same signs in urban and rural markets. Only two of the coefficients differ significantly between urban and rural markets. The presence of sectoral clusters lower employment in both markets, with the larger effect in urban areas. Monopoly opportunity retains its negative effect on employment growth but the effect is now larger in rural areas. None of the coefficients differ between adjacent and remote rural counties.

The elasticities by market type are reported to the right of the estimates in Table 5 . The main differences between these results based on the aggregated data on net employment growth and our previous results based on firm entry are the much smaller elasticities and the switched signs on cluster specialization $\left(C L U_{k c}\right)$. There may be a negative relationship between productivity and employment. As pointed out in Cingano and Schivardi (2004), if

${ }^{25}$ There are 22,288 potential industry-county pairs with 112 industries and 199 counties. We excluded two industries or 398 industry-county pairs because they did not have any new firm entrants in 2001 and so those sectors would not have been included in our previous analysis. 
the price elasticity of demand is inelastic in an industry, productivity improvements can reduce revenue and labor demand. However, the other agglomeration measures are positively correlated with employment growth and so the Cingano and Schivardi argument does not resolve the problem. Moreover, in the aggregate, productivity growth and employment are highly positively correlated in the United States and so the empirical basis for the argument is also suspect. ${ }^{26}$

A more compelling argument for the smaller elasticities in Table 5 compared to Table 3 is that at the market level of aggregation, current employment is a primarily the aggregation of past employment decisions made by firms that entered the market under past market conditions and agglomeration levels. Costs of relocation are prohibitive, and so firms may not be in their best location given current market conditions. Consequently, the link between agglomeration measures and the growth of incumbent firms must be weaker than the link between agglomeration factors and the location decisions of entering firms.

More importantly, our conditional logit specification estimating equation (5) controls for the unobserved firm profit component, $\varepsilon_{i}$, while the estimation using the county aggregate net sectoral employment data does not. These unobserved firm fixed effects are likely to affect the pace of future firm investment, employment and production decisions, so they will create unobserved location-specific profitability and productivity factors that are almost certainly correlated with the observed agglomeration measures. Hence, the coefficients and the elasticities in Table 5 are biased and will not yield reliable inferences regarding the role of agglomeration economies on county-sector growth.

\section{Agglomeration economies and commuting patterns}

As a second robustness check, we examine the linkage between agglomeration economies

\footnotetext{
26 The simple correlation between output per worker and aggregate hours employed from 1947-2013 is 0.98, using the U.S. Bureau of Labor Statistics' Major Sector Productivity Series for the nonfarm business sector.
} 
and commuting patterns. In theory, agglomeration economies will raise location-specific productivity, some of which will be captured by workers in the form of higher wages. That will create an incentive for workers in low agglomeration locations to move to or commute to locations with greater agglomeration levels. Importantly, the cost of switching job locations within a 2-3 county radius is relatively low compared to the potential returns and so commuting decisions can respond more elastically to changing market conditions than can firms.

There is evidence suggesting that commuting is sensitive to local job growth. Renkow (2003) found that a substantial portion (one-third to one-half) of new jobs is taken by in-commuters. Khan et al. (2001) found that economic growth in one community positively interacts with growth in nearby communities, possibly through commuting. Because we show that agglomeration economies increase new firm entry, we can conjecture that commuting is sensitive to agglomeration economies as well. However, testing this hypothesis has been limited due to the difficulty in measuring magnitudes of local agglomeration economies. Recent commuting studies measured the spillover of urban agglomeration economies to rural towns using the distance between urban centers and rural towns (Ali et al., 2011; Partridge et al., 2010), but this measure does not capture variations in agglomeration economies within rural or urban areas.

To test the importance of these agglomeration economies on commuting patterns, we consider a commuting destination decision of workers. Suppose that a worker $i$ living in a home county $h(h=1, \ldots, H)$ chooses a county $d$ for work $(d=1, \ldots, D) . \quad D$ counties are located within commuting distance which we set arbitrarily at 100 miles from her home county. The choice set of potential counties of work varies with the location of each county of 
residence. $^{27}$

We assume a latent utility function of worker $i$ living in a home county $h$ and working in a county $d$ below. As in our analysis of new firm entry, we assume a spatial equilibrium model where wages and rents are functions of local factors affecting firm productivity (Rosen, 1979; Roback, 1982). Workers choose the county for work that gives them the highest utility conditional on residing county $h$ :

$$
U_{i h d}=\beta_{A} \frac{A E_{d}}{A E_{h}}+\beta_{D} D I S T_{h d}+\beta_{U} U R B_{d}+\beta_{F} \frac{F I R M_{d}}{F I R M_{h}}+\varepsilon_{h}+u_{i h d}
$$

The explanatory variables are lagged and pre-determined at the time of the commuting destination decision. For notational convenience, we omit a subscript for time period.

The first term is the ratio of the agglomeration economy at the destination county relative to the county of residence. Based on (5), we estimate the agglomeration index for each county by

$$
A E_{i k c} \equiv \frac{\exp \left(m_{k c}^{\prime} \cdot \gamma_{m}+m_{k c}^{\prime} \cdot U R B_{c} \cdot \gamma_{m u}+m_{k c}^{\prime} \cdot R_{-} A D J_{c} \cdot \gamma_{m a}\right)}{\sum_{c} \exp \left(m_{k c}^{\prime} \cdot \gamma_{m}+m_{k c}^{\prime} \cdot U R B_{c} \cdot \gamma_{m u}+m_{k c}^{\prime} \cdot R_{-} A D J_{c} \cdot \gamma_{m a}+z_{k c}^{\prime} \cdot \gamma_{z}\right)}
$$

where the coefficients are taken from Table 2. This index is the contribution of the six agglomeration economy measures to the probability of new-firm entry in county $c$, relative to the probability of entry across all counties. We take the average across all firms to obtain the unconditional estimate of $A E_{c}$. Note that the ratio will be greater than one when a county within 100 miles has a larger level of agglomeration than the home county. When $h=d$, meaning the worker lives and works in the home county, the ratio is 1. If agglomeration economies raise productivity, they should raise wages as well, and so a county $d$ with a high level of agglomeration should attract more commuters from neighboring counties.

${ }^{27}$ In our commuting data, $94 \%$ of workers commuting within a state (Iowa or North Carolina) commute to a county within 100 miles from their home county. We do not allow commuting across states because of data complications. Both North Carolina and Iowa have metropolitan areas that cross state lines, making it difficult to distinguish agglomeration levels across counties with in the same metropolitan area. 
Commuting distance from a home county $h$ to a county $d\left(D I S T_{h d}\right)$ raises the cost of commuting, and so probability of commuting should decrease as distance increases. $U R B_{d}$ indicates whether the commuting destination $d$ is urban, and captures unobservable local factors other than our observed agglomeration measures that may influence commuting. $F I R M_{d} / F I R M_{h}$ is the proportion of existing firms in county $d$ relative to in county $h$. We add $F I R M_{d} / F I R M_{h}$ to take out the effect of relative county size so that the relationship between agglomeration measures and commuting patterns is not just a reflection of county size. The error term, $\varepsilon_{h}$, represents home-county-specific unobservable impacts, and is differenced away in the conditional logit estimation because it does not affect the relative utilities across counties. We assume that $u_{i h d}$ is a random error not correlated with the explanatory variables. We estimate the utility function using the conditional logit estimation. $^{28}$ This framework is similar to the population migration study of Davies et al. (2001).

We obtain commuting patterns in Iowa and North Carolina from the 2006-2010 American Community Survey County-to-County Worker Flow File, U.S. Census Bureau. Distances between the geographical centroids of two counties were compiled using the County-to-County Distance Matrix at the Center for Transportation Analysis, Oak Ridge National Laboratory. Rural-urban classification is the same as in the previous new-firm entry analysis. The number of existing firms is aggregated from the firm level data in the National Establishment Time Series (NETS) in year 2000.

Results are reported in Table 6 with elasticities in brackets. Consistent with the analysis of new firm entry, there is a very strong positive relationship between our estimate of the effect of agglomeration measures on firm entry and the probability of in-commuting. Thus, the same agglomeration factors that encourage firm entry also atypically attract

${ }^{28}$ We used the grouped conditional logit with a STATA command "multin." 
workers from other counties. The effect remains strong even when we control for the relative number of firms and the urban designation of the county. The literal interpretation is that a $10 \%$ increase in the probability of new firm entry in a county attributable to growth in agglomeration results in a $2 \%$ increase in the probability of in-commuting from a county within a 100 mile radius. Meanwhile, distance has a strong negative effect on the probability of commuting, whether from a rural or urban county of residence.

The adverse impact of distance on commuting is of like magnitude for urban and rural residences. However, the attraction of greater agglomeration in a neighboring county is 3 times larger ( 0.42 versus 0.14 ) for rural county residents compared to urban county residents. As a result, a given incremental return in relative agglomeration will attract rural in-commuters from a greater distance than for urban in-commuters.

\section{Discussion: integration between small and large rural towns}

We have shown that the same agglomeration measures that have been associated with urban economic growth are important for rural economic growth as well. The pattern holds for both stand-alone ventures and for multi-plant firms looking to expand into new markets. The relative sizes of the elasticities of the agglomeration measures are consistent between urban and rural areas regardless of industry classification (all industries vs. manufacturing) and establishment ownership (stand-alone vs. expansion). Commuters are attracted to the same agglomeration factors that attract new firm start-ups.

Our results have two useful implications to theories in local agglomeration economies. First, our results can test several theories related to agglomeration economies for rural areas similar to Glaeser (1992) et al. did for urban areas. Our results imply that the most attractive areas for new firm entry are diverse economies with proximate upstream and downstream firms, an available educated workforce and a ready number of firms already in the sector. Our results support the various theories of local economic growth including 
Jacobs' (1969) importance of diversity, Porter's (1990) emphasis on clusters, Lucas's (1988) and Romer's (1986) endogenous growth based on concentrations of an educated workforce and Marshall's theory of proximate upstream and downstream firms. But we find no support for Marshall's (1920) and Schumpeter's (1942) view that monopoly opportunity invites entry in order to exploit first mover rents; in contrast, more competitive markets seem to induce firm entry.

Second, our results provide a dynamic context for Central Place Theory (CPT) initiated by Christaller (1933). One of the key components in CPT is a persistent urban hierarchy; larger cities have more industries because higher-ordered industries require higher demand thresholds. As mentioned in Mulligan et al. (2012), CPT does not have a sufficient dynamic explanation of how urban hierarchy persists. Our finding that agglomeration attracts new firm entry relative to less agglomerated markets means that the most agglomerated will get the largest annual infusion of new firms. Consequently, agglomeration economies are a key reason that the urban hierarchy persists.

Based on our findings, we expect that rural communities with higher agglomeration economies will serve as regional centers of economic activity with their surrounding communities providing labor and customers who commute in. Rural communities that do not have a critical mass of firm clusters, upstream suppliers, downstream customers and educated labor will find it difficult to attract new start-ups. Policies aimed at encouraging new firm entry in dispersed small towns that lack agglomeration externalities would be much more expensive and will likely fail (Barkley and Henry, 1997). In addition, recruiting new firms that do not exist in the rural town would require additional costs because no incumbent firms in the industry would be a signal that the industry has no advantages in the town. The more promising strategy is to target new firm recruitment to the relatively few rural markets that have managed to foster sufficient agglomeration economies that they can attract both 
firms and commuting workers. ${ }^{29}$

Our findings call into question the efficacy of rural development policies that aim to improve economic growth in all rural towns. A "greatest potential" type approach that targets rural towns with growth potential, as evidenced by the existence of agglomeration economies, and promotes them as local job centers would be economically promising.

While that means many small rural towns will continue to experience population loss, overall, a more targeted policy may stabilize regional rural population.

29 Our approach can be compared with Kilkenny and Johnson (2007) and Olfert and Partridge (2010). Kilkenny and Johnson argued in favor of community-level adjustments to make fewer, larger and more prosperous rural communities. While their goal is similar to ours, their approach is different. They suggest merging small rural towns jurisdictionally or physically while we suggest integration between small rural communities and rural regional job centers, possibly through better roads and improved telecommunications. Olfert and Partridge emphasized the integration between rural towns and urban centers to take advantage of the spillover of urban agglomeration economies to rural towns. Their approach focuses on in-migration from urban areas and out-commuting to urban areas, while we focus on job creation in large rural towns with incommuting from surrounding smaller rural communities. 


\section{References}

Ali, Kamar; M Rose Olfert and Mark D Partridge. 2011. "Urban Footprints in Rural Canada: Employment Spillovers by City Size." Regional Studies, 45(2), 239-60.

Barkley, David L and Mark S Henry. 1997. "Rural Industrial Development: To Cluster or Not to Cluster?" Review of Agricultural Economics, 19(2), 308-25.

Barkley, David L; Mark S Henry and Shuming Bao. 1996. "Identifying" Spread" Versus" Backwash" Effects in Regional Economic Areas: A Density Functions Approach." Land Economics, 336-57.

Barkley, David L.; Mark S. Henry and Yunsoo Kim. 1999. "Industry Agglomerations and Employment Change in Non-Metropolitan Areas." Review of Urban \& Regional Development Studies, 11(3), 168-86.

Barkley, David L. and John E. Keith. 1991. "The Locational Determinants of Western Nonmetro High Tech Manufacturers: An Econometric Analysis." Western Journal of Agricultural Economics, 16(2), 331-44.

Castle, Emery N; JunJie Wu and Bruce A Weber. 2011. "Place Orientation and Rural-Urban Interdependence." Applied Economic Perspectives and Policy, 33(2), 179-204.

Christaller, Walter. 1933. Die Zentralen Orte in Süddeutschland. Central Places in Southern Germany; Translated by Carlisle W. Baskin. Prentice-Hall.

Cingano, Federico and Fabiano Schivardi. 2004. "Identifying the Sources of Local Productivity Growth." Journal of the European Economic Association, 2(4), 720-44.

Davies, Paul S; Michael J Greenwood and Haizheng Li. 2001. "A Conditional Logit Approach to Us State-to-State Migration." Journal of Regional Science, 41(2), 337-60.

De Blasio, Guido and Sabrina Di Addario. 2005. "Do Workers Benefit from Industrial Agglomeration?*." Journal of Regional Science, 45(4), 797-827.

Delfmann, Heike; Sierdjan Koster; Philip McCann and Jouke Van Dijk. 2014. "Population Change and New Firm Formation in Urban and Rural Regions." Regional Studies, 48(6), 1034-50.

Delgado, Mercedes; Michael E. Porter and Scott Stern. 2010. "Clusters and Entrepreneurship." Journal of Economic Geography, 10(4), 495-518.

Duranton, Gilles. 2011. "California Dreamin': The Feeble Case for Cluster Policies." Review of Economic Analysis, 3(1), 3-45.

Duranton, Gilles and Diego Puga. 2014. "Chapter 5 - the Growth of Cities," A. Philippe and N. D. Steven, Handbook of Economic Growth. Elsevier, 781-853. . 2004. "Chapter 48 Micro-Foundations of Urban Agglomeration Economies," J. V. Henderson and T. Jacques-François, Handbook of Regional and Urban Economics. Elsevier, 2063-117. 
Ellison, Glenn; Edward L. Glaeser and William R. Kerr. 2010. "What Causes Industry Agglomeration? Evidence from Coagglomeration Patterns." The American Economic Review, 100(3), 1195-213.

Feldman, Maryann P. and David B. Audretsch. 1999. "Innovation in Cities:: Science-Based Diversity, Specialization and Localized Competition." European Economic Review, 43(2), 409-29.

Freire-Gibb, Lucio Carlos and Kristian Nielsen. 2014. "Entrepreneurship within Urban and Rural Areas: Creative People and Social Networks." Regional Studies, 48(1), 139-53.

Gabe, Todd. 2003. "Local Industry Agglomeration and New Business Activity." Growth and Change, 34(1), 17-39.

Gabe, Todd M. 2005. "Industry Agglomeration and Investment in Rural Businesses." Applied Economic Perspectives and Policy, 27(1), 89-103.

Gibbs, Robert M and G Andrew Bernat. 1997. "Rural Industry Clusters Raise Local Earnings." Rural Development Perspectives, 12, 18-25.

Glaeser, Edward L. and Joshua D. Gottlieb. 2009. "The Wealth of Cities: Agglomeration Economies and Spatial Equilibrium in the United States." Journal of Economic Literature, 47(4), 983-1028.

Glaeser, Edward L.; Hedi D. Kallal; José A. Scheinkman and Andrei Shleifer. 1992. "Growth in Cities." Journal of Political Economy, 100(6), 1126-52.

Glaeser, Edward L. and William R. Kerr. 2009. "Local Industrial Conditions and Entrepreneurship: How Much of the Spatial Distribution Can We Explain?" Journal of Economics \& Management Strategy, 18(3), 623-63.

Glaeser, Edward L.; William R. Kerr and Giacomo A. M. Ponzetto. 2010. "Clusters of Entrepreneurship." Journal of Urban Economics, 67(1), 150-68.

Glaeser, Edward L and David C Maré. 2001. "Cities and Skills." Journal of Labor Economics, 19(2), 316-42.

Guimaraes, Paulo and Richard C Lindrooth. 2007. "Controlling for Overdispersion in Grouped Conditional Logit Models: A Computationally Simple Application of DirichletMultinomial Regression." The Econometrics Journal, 10(2), 439-52.

Helsley, Robert W and William C Strange. 2002. "Innovation and Input Sharing." Journal of Urban Economics, 51(1), 25-45.

Henderson, J. Vernon. 2003. "Marshall's Scale Economies." Journal of Urban Economics, 53(1), 1-28.

Henderson, Vernon; Ari Kuncoro and Matt Turner. 1995. "Industrial Development in Cities." Journal of Political Economy, 103(5), 1067-90.

Henry, Mark and Mark Drabenstott. 1996. "A New Micro View of the Us Rural Economy." 
Economic Review-Federal Reserve Bank of Kansas City, 81, 53-70.

Irwin, Elena G; Andrew M Isserman; Maureen Kilkenny and Mark D Partridge. 2010. "A Century of Research on Rural Development and Regional Issues." American Journal of Agricultural Economics, 92(2), 522-53.

Jacobs, Jane. 1969. The Economy of Cities. New York: Random House.

Jofre-Monseny, Jordi; Raquel Marín-López and Elisabet Viladecans-Marsal. 2011. "The Mechanisms of Agglomeration: Evidence from the Effect of Inter-Industry Relations on the Location of New Firms." Journal of Urban Economics, 70(2-3), 61-74.

Khan, Romana; Peter F Orazem and Daniel M Otto. 2001. "Deriving Empirical Definitions of Spatial Labor Markets: The Roles of Competing Versus Complementary Growth." Journal of Regional Science, 41(4), 735-56.

Kilkenny, Maureen. 1998. "Transport Costs and Rural Development." Journal of Regional Science, 38(2), 293-312. . 2010. "Urban / Regional Economics and Rural Development." Journal of Regional Science, 50(1), 449-70.

Kilkenny, M. and S. Johnson. 2007. "Rural Development Policy," B. G. and and D. Sumner, Agricultural Policy for 2007 Farm Bill and Beyond. Washington, D.C.: American Enterprise Institute.

Lucas Jr, Robert E. 1988. "On the Mechanics of Economic Development." Journal of Monetary Economics, 22(1), 3-42.

Marshall, Alfred. 1920. Principles of Economics. London: Macmillan

Melo, Patricia C; Daniel J Graham and Robert B Noland. 2009. "A Meta-Analysis of Estimates of Urban Agglomeration Economies." Regional Science and Urban Economics, 39(3), 332-42.

Moretti, Enrico. 2004. "Workers' Education, Spillovers, and Productivity: Evidence from Plant-Level Production Functions." The American Economic Review, 94(3), 656-90.

Mulligan, Gordon F; Mark D Partridge and John I Carruthers. 2012. "Central Place Theory and Its Reemergence in Regional Science." The Annals of Regional Science, 48(2), $405-$ 31 .

Olfert, M and Mark D Partridge. 2010. "Best Practices in Twenty-First-Century Rural Development and Policy." Growth and Change, 41(2), 147-64.

Partridge, Mark; Ray D Bollman; M Rose Olfert and Alessandro Alasia. 2007. "Riding the Wave of Urban Growth in the Countryside: Spread, Backwash, or Stagnation?" Land Economics, 83(2), 128-52.

Partridge, Mark D; Kamar Ali and M Olfert. 2010. "Rural-to-Urban Commuting: Three Degrees of Integration." Growth and Change, 41(2), 303-35. 
Partridge, Mark D; Dan S Rickman; Kamar Ali and M Rose Olfert. 2008. "Lost in Space: Population Growth in the American Hinterlands and Small Cities." Journal of Economic Geography, 8(6), 727-57.

Porter, Michael. 2003. "The Economic Performance of Regions." Regional Studies, 37(6-7), 545-46.

Porter, Michael E. 1990. The Competitive Advantage of Nations. New York: Free Press.

Puga, Diego. 2010. "The Magnitude and Causes of Agglomeration Economies." Journal of Regional Science, 50(1), 203-19.

Renkow, Mitch. 2003. "Employment Growth, Worker Mobility, and Rural Economic Development." American Journal of Agricultural Economics, 85(2), 503-13.

Renkow, Mitch and Dale Hoover. 2000. "Commuting, Migration, and Rural-Urban Population Dynamics." Journal of Regional Science, 40(2), 261-87.

Renski, Henry. 2008. "New Firm Entry, Survival, and Growth in the United States: A Comparison of Urban, Suburban, and Rural Areas." Journal of the American Planning Association, 75(1), 60-77.

Renski, Henry and Ryan Wallace. 2012. "Entrepreneurship in Rural America." Financing Economic Development in the 21st Century, 245.

Roback, Jennifer. 1982. "Wages, Rents, and the Quality of Life." Journal of Political Economy, 90(6), 1257-78.

Romer, Paul M. 1986. "Increasing Returns and Long-Run Growth." Journal of Political Economy, 94(5), 1002-37.

Rosen, Sherwin. 1979. "Wage-Based Indexes of Urban Quality of Life," P. Mieszkowski and M. Straszheim, Current Issues in Urban Economics. Baltimore: Johns Hopkins Univ. Press, 391-429.

Rosenthal, Stuart S. and William C. Strange. 2008. "The Attenuation of Human Capital Spillovers." Journal of Urban Economics, 64(2), 373-89. . 2004. "Evidence on the Nature and Sources of Agglomeration Economies," J. V. Henderson and T. Jacques-François, Handbook of Regional and Urban Economics. Elsevier, 2119-71. . 2003. "Geography, Industrial Organization, and Agglomeration." review of Economics and Statistics, 85(2), 377-93.

Schumpeter, Joseph A. 1942. Capitalism, Socialism, and Democracy. London: Harper \& Brothers.

Shapiro, Jesse M. 2006. "Smart Cities: Quality of Life, Productivity, and the Growth Effects of Human Capital." The Review of Economics and Statistics, 88(2), 324-35. 
Smith, Stephen M and David L Barkley. 1988. "Labor Force Characteristics of 'High Tech'vs.'Low Tech'manufacturing in Nonmetropolitan Counties in the West." Community Development, 19(1), 21-36.

Wheaton, William C. and Mark J. Lewis. 2002. "Urban Wages and Labor Market Agglomeration." Journal of Urban Economics, 51(3), 542-62.

Winters, John V. 2013. "Human Capital Externalities and Employment Differences across Metropolitan Areas of the USA." Journal of Economic Geography, 13(5), 799-822.

Wu, JunJie and Munisamy Gopinath. 2008. "What Causes Spatial Variations in Economic Development in the United States?" American Journal of Agricultural Economics, 90(2), 392-408.

Yu, Li; Peter F Orazem and Robert W Jolly. 2011. "Why Do Rural Firms Live Longer?" American Journal of Agricultural Economics, 93(3), 669-88. 
Table 1 Summary statistics of agglomeration measures in Iowa and North Carolina in 2000

\begin{tabular}{|c|c|c|c|c|c|c|c|c|}
\hline & \multicolumn{4}{|c|}{ Urban county } & \multicolumn{4}{|c|}{ Rural county } \\
\hline & Mean & Std. Dev. & Min. & Max. & Mean & Std. Dev. & Min. & Max. \\
\hline$C L U_{k c}:$ Location quotient in $k, c$ & 1.05 & 1.05 & 0.00 & 16.43 & 0.77 & 1.39 & 0.00 & 36.15 \\
\hline$M O N_{k c}:$ No incumbent in $k$ & 0.17 & 0.37 & 0.00 & 1.00 & 0.40 & 0.49 & 0.00 & 1.00 \\
\hline$U P_{k c}:$ Proximity to upstream firms & 1.27 & 1.79 & 0.02 & 15.93 & 0.21 & 0.24 & 0.00 & 7.24 \\
\hline$D O W N_{k c}$ : Proximity to downstream firms & 1.11 & 1.51 & 0.00 & 15.76 & 0.21 & 0.26 & 0.00 & 8.66 \\
\hline $\begin{array}{l}C O N_{c}: \text { Herfindahl Index in county } c \\
E D U_{c}: \text { Share of population with } 14+\text { years of }\end{array}$ & 0.22 & 0.07 & 0.14 & 0.50 & 0.24 & 0.08 & 0.14 & 0.58 \\
\hline schooling & 0.28 & 0.10 & 0.13 & 0.57 & 0.22 & 0.05 & 0.14 & 0.52 \\
\hline \# of counties & & 45 & & & & 154 & & \\
\hline
\end{tabular}

Rural counties are statistically different from urban counties in terms of the agglomeration measures at $1 \%$ significance level in the two-sample $\mathrm{z}$-test. The test statistics are larger than at least 13.2 in absolute value sense. 
Table 2 Location choice of new firms in Iowa and North Carolina counties in 2000-2002

\begin{tabular}{|c|c|c|c|c|c|c|c|c|c|c|c|c|}
\hline \multirow{3}{*}{$\begin{array}{l}\text { Dependent var.: choice } \\
\text { of county } \\
C L U_{k c}\end{array}$} & \multicolumn{6}{|c|}{ All industries } & \multicolumn{6}{|c|}{ Manufacturing } \\
\hline & \multicolumn{2}{|r|}{ (1) } & \multicolumn{2}{|c|}{ (2) } & \multicolumn{2}{|c|}{ (3) } & \multicolumn{2}{|r|}{ (4) } & \multicolumn{2}{|c|}{ (5) } & \multicolumn{2}{|r|}{ (6) } \\
\hline & 0.28 & $(<0.01)^{* * *}$ & 0.23 & $(<0.01)^{* * *}$ & 0.21 & $(0.01)^{* * *}$ & 0.18 & $(0.01) * * *$ & 0.14 & $(0.01)^{* * *}$ & 0.11 & $(0.01)^{* * *}$ \\
\hline$M O N_{k c}$ & -0.65 & $(0.03) * * *$ & -0.38 & $(0.04)^{* * *}$ & -0.38 & $(0.05)^{* * *}$ & -0.41 & $(0.05) * * *$ & -0.28 & $(0.06)^{* * *}$ & -0.25 & $(0.08) * * *$ \\
\hline$U P_{k c}$ & 0.15 & $(<0.01)^{* * *}$ & 1.29 & $(0.02)^{* * *}$ & 1.59 & $(0.04)^{* * *}$ & 0.08 & $(0.01)^{* * *}$ & 0.76 & $(0.05)^{* * *}$ & 0.56 & $(0.10) * * *$ \\
\hline$D O W N_{k c}$ & 0.05 & $(<0.01)^{* * *}$ & 0.29 & $(0.01)^{* * *}$ & 0.50 & $(0.02) * * *$ & 0.20 & $(0.01)^{* * *}$ & 0.34 & $(0.03)^{* * *}$ & 0.88 & $(0.10) * * *$ \\
\hline$C O N_{c}$ & -1.31 & $(0.04)^{* * *}$ & -0.46 & $(0.06)^{* * *}$ & -0.92 & $(0.10) * * *$ & -1.47 & $(0.22) * * *$ & -0.76 & $(0.29)^{* * *}$ & -1.13 & $(0.50)^{* *}$ \\
\hline$E D U_{c}$ & 2.31 & $(0.03)^{* * *}$ & 1.51 & $(0.07)^{* * *}$ & 1.65 & $(0.14)^{* * *}$ & 1.82 & $(0.17)^{* * *}$ & 2.63 & $(0.35)^{* * *}$ & 2.85 & $(0.65) * * *$ \\
\hline$U R B_{c} \times C L U_{k c}$ & - & & 0.15 & $(0.01)^{* * *}$ & 0.17 & $(0.01)^{* * *}$ & - & & 0.10 & $(0.01)^{* * *}$ & 0.13 & $(0.02) * * *$ \\
\hline$U R B_{c} \times M O N_{k c}$ & - & & -0.07 & $(0.09)$ & -0.05 & $(0.09)$ & - & & -0.22 & $(0.11)^{* *}$ & -0.25 & $(0.13) *$ \\
\hline$U R B_{c} \times U P_{k c}$ & - & & -1.13 & $(0.02) * * *$ & -1.42 & $(0.04) * * *$ & - & & -0.67 & $(0.05) * * *$ & -0.48 & $(0.10)^{* * *}$ \\
\hline$U R B_{c} \times D O W N_{k c}$ & - & & -0.24 & $(0.01)^{* * *}$ & -0.45 & $(0.02)^{* * *}$ & - & & -0.15 & $(0.03)^{* * *}$ & -0.69 & $(0.10) * * *$ \\
\hline$U R B_{c} \times C O N_{c}$ & - & & -2.34 & $(0.09) * * *$ & -1.86 & $(0.13)^{* * *}$ & - & & -1.66 & $(0.44)^{* * *}$ & -1.25 & $(0.61)^{* *}$ \\
\hline$U R B_{c} \times E D U_{c}$ & - & & 0.22 & $(0.08) * * *$ & 0.08 & $(0.14)$ & - & & -0.98 & $(0.38) * * *$ & -1.19 & $(0.66) *$ \\
\hline$R \_A D J_{c} \times C L U_{k c}$ & - & & - & & 0.07 & $(0.01)^{* * *}$ & - & & - & & 0.06 & $(0.02)^{* * *}$ \\
\hline$R \_A D J_{c} \times M O N_{k c}$ & - & & - & & 0.06 & $(0.07)$ & - & & - & & -0.01 & $(0.12)$ \\
\hline$R \_A D J_{c} \quad \mathrm{x} U P_{k c}$ & - & & - & & -0.33 & $(0.04)^{* * *}$ & - & & - & & 0.27 & $(0.11)^{*}$ \\
\hline$R \_A D J_{c} \quad$ x $D O W N_{k c}$ & - & & - & & -0.23 & $(0.02)^{* * *}$ & - & & - & & -0.59 & $(0.11) * * *$ \\
\hline$R \_A D J_{c} \times C O N_{c}$ & - & & - & & 0.75 & $(0.12) * * *$ & - & & - & & 0.62 & $(0.62)$ \\
\hline$R \_A D J_{c} \times E D U_{c}$ & - & & - & & -0.38 & $(0.16)^{* *}$ & - & & - & & -0.44 & $(0.74)$ \\
\hline \# of est. / \# of counties & & & 191, & $191 / 199$ & & & & & & 74 / 196 & & \\
\hline
\end{tabular}

Notes: Estimates are based on the conditional logit estimation. Standard errors are in parentheses. ***: significant at $1 \%$, **: significant at $5 \%$, *: significant at $10 \%$. Estimates for control variables $\left(I N C_{c}, U R B_{c}, R A D J_{c}, R B I G_{c}\right.$, and $\left.N C_{c}\right)$ are not reported. 
Table 3 Elasticities of agglomeration measures on probability of new firm entry

(a) By all industries and manufacturing

\begin{tabular}{|c|c|c|c|c|c|c|c|c|c|c|}
\hline & \multicolumn{5}{|c|}{ All industries } & \multicolumn{5}{|c|}{ Manufacturing } \\
\hline & $\begin{array}{c}\text { Urban } \\
\text { (1) }\end{array}$ & Rural & $\begin{array}{l}\text { Urban } \\
\text { (3) }\end{array}$ & $\begin{array}{l}\text { Rural: } \\
\text { Adjacent to } \\
\text { urban } \\
(4)\end{array}$ & $\begin{array}{c}\text { Rural: } \\
\text { Remote from } \\
\text { urban } \\
(5) \\
\end{array}$ & $\begin{array}{c}\text { Urban } \\
(6) \\
\end{array}$ & Rural & $\begin{array}{l}\text { Urban } \\
\text { (8) }\end{array}$ & $\begin{array}{l}\text { Rural: } \\
\text { Adjacent to } \\
\text { urban } \\
(9)\end{array}$ & $\begin{array}{l}\text { Rural: Remote } \\
\text { from urban } \\
(10)\end{array}$ \\
\hline$C L U_{k c}$ & 0.23 & 0.19 & 0.22 & 0.20 & 0.18 & 0.15 & 0.12 & 0.13 & 0.12 & 0.10 \\
\hline$M O N_{k c}$ & $\{-0.38\}$ & $\{-0.32\}$ & $\{-0.37\}$ & $\{-0.26\}$ & $\{-0.32\}$ & $\{-0.46\}$ & $\{-0.26\}$ & $\{-0.45\}$ & $\{-0.24\}$ & $\{-0.23\}$ \\
\hline$U P_{k c}$ & 0.25 & 0.58 & 0.30 & 0.68 & 0.71 & 0.15 & 0.33 & 0.12 & 0.27 & 0.24 \\
\hline$D O W N_{k c}$ & 0.06 & 0.11 & 0.09 & 0.18 & 0.20 & 0.10 & 0.13 & 0.18 & 0.29 & 0.34 \\
\hline$C O N_{c}$ & -0.22 & -0.11 & -0.31 & -0.15 & -0.22 & -0.26 & -0.18 & -0.33 & -0.21 & -0.27 \\
\hline$E D U_{c}$ & 0.36 & 0.35 & 0.38 & 0.35 & 0.38 & 0.54 & 0.61 & 0.58 & 0.62 & 0.66 \\
\hline
\end{tabular}

Notes: Elasticities based on conditional logit results reported in Table 2. The results reported in brackets for monopoly opportunity $M O N_{k c}$ are proportional changes in the probability of firm entry going from the absence of a monopoly to the presence of a monopoly in the county-sector market.

(b) By establishment ownership

\begin{tabular}{|c|c|c|c|c|c|c|c|c|c|c|}
\hline & \multicolumn{5}{|c|}{ Expansion start-up } & \multicolumn{5}{|c|}{ Standalone start-up } \\
\hline & $\begin{array}{r}\text { Urban } \\
(1) \\
\end{array}$ & Rural & $\begin{array}{c}\text { Urban } \\
\text { (3) }\end{array}$ & $\begin{array}{l}\text { Rural: } \\
\text { Adjacent to } \\
\text { urban } \\
(4)\end{array}$ & $\begin{array}{l}\text { Rural: Remote } \\
\text { from urban } \\
\text { (5) }\end{array}$ & $\begin{array}{c}\text { Urban } \\
\text { (6) }\end{array}$ & Rural & $\begin{array}{c}\text { Urban } \\
\text { (8) }\end{array}$ & $\begin{array}{l}\text { Rural: } \\
\text { Adjacent to } \\
\text { urban } \\
(9)\end{array}$ & $\begin{array}{l}\text { Rural: Remote } \\
\text { from urban } \\
(10)\end{array}$ \\
\hline$C L U_{k c}$ & 0.20 & 0.17 & 0.19 & 0.17 & 0.16 & 0.23 & 0.20 & 0.21 & 0.19 & 0.17 \\
\hline$M O N_{k c}$ & $\{-0.57\}$ & $\{-0.48\}$ & $\{-0.60\}$ & $\{-0.74\}$ & $\{-0.32\}$ & $\{-0.33\}$ & $\{-0.27\}$ & $\{-0.29\}$ & $\{-0.25\}$ & $\{-0.35\}$ \\
\hline$U P_{k c}$ & 0.17 & 0.36 & 0.20 & 0.42 & 0.44 & 0.28 & 0.65 & 0.37 & 0.86 & 0.90 \\
\hline$D O W N_{k c}$ & 0.10 & 0.20 & 0.16 & 0.31 & 0.34 & 0.05 & 0.09 & 0.08 & 0.17 & 0.19 \\
\hline$C O N_{c}$ & -0.21 & -0.07 & -0.43 & -0.19 & -0.35 & -0.21 & -0.10 & -0.21 & -0.04 & -0.10 \\
\hline$E D U_{c}$ & 0.46 & 0.47 & 0.30 & 0.33 & 0.24 & 0.34 & 0.32 & 0.54 & 0.49 & 0.60 \\
\hline
\end{tabular}

Notes: Elasticities based on conditional logit results reported in Table 4 . The results reported in brackets for monopoly opportunity $M O N_{k c}$ are proportional changes in the probability of firm entry going from the absence of a monopoly to the presence of a monopoly in the county-sector market. 
Table 4 Location choice of new firms by establishment ownership: Iowa and North Carolina counties in 2000-2002

\begin{tabular}{|c|c|c|c|c|c|c|c|c|c|c|c|c|}
\hline \multirow{3}{*}{$\begin{array}{l}\text { Dependent var.: choice } \\
\text { of county } \\
C L U_{k c}\end{array}$} & \multicolumn{6}{|c|}{ Expansion start-up } & \multicolumn{6}{|c|}{ Standalone start-up } \\
\hline & \multicolumn{2}{|r|}{ (1) } & \multicolumn{2}{|c|}{$(2)$} & \multicolumn{2}{|r|}{ (3) } & \multicolumn{2}{|r|}{ (4) } & \multicolumn{2}{|r|}{$(5)$} & \multicolumn{2}{|r|}{ (6) } \\
\hline & 0.23 & $(0.01)^{* * *}$ & 0.20 & $(0.01)^{* * *}$ & 0.18 & $(0.02)^{* * *}$ & 0.29 & $(<0.01) * * *$ & 0.23 & $(0.01)^{* * *}$ & 0.20 & $(0.01)^{* * *}$ \\
\hline$M O N_{k c}$ & -0.90 & $(0.10)^{* * *}$ & -0.61 & $(0.11)^{* * *}$ & -0.38 & $(0.14) * * *$ & -0.60 & $(0.04) * * *$ & -0.32 & $(0.04)^{* * *}$ & -0.43 & $(0.05) * * *$ \\
\hline$U P_{k c}$ & 0.14 & $(0.01)^{* * *}$ & 0.82 & $(0.04) * * *$ & 1.01 & $(0.08) * * *$ & 0.16 & $(<0.01) * * *$ & 1.44 & $(0.02)^{* * *}$ & 2.01 & $(0.04) * * *$ \\
\hline$D O W N_{k c}$ & 0.12 & $(0.01)^{* * *}$ & 0.49 & $(0.03) * * *$ & 0.85 & $(0.08) * * *$ & 0.05 & $(<0.01)^{* * *}$ & 0.24 & $(0.01)^{* * *}$ & 0.48 & $(0.02)^{* * *}$ \\
\hline$C O N_{c}$ & -1.33 & $(0.17)^{* * *}$ & -0.31 & $(0.23)$ & -1.48 & $(0.42)^{* * *}$ & -1.30 & $(0.05) * * *$ & -0.44 & $(0.06)^{* * *}$ & -0.41 & $(0.11)^{* * *}$ \\
\hline$E D U_{c}$ & 2.55 & $(0.12)^{* * *}$ & 2.03 & $(0.28) * * *$ & 1.04 & $(0.54)^{* *}$ & 2.29 & $(0.03)^{* * *}$ & 1.38 & $(0.07)^{* * *}$ & 2.60 & $(0.14)^{* * *}$ \\
\hline$U R B_{c} \times C L U_{k c}$ & - & & 0.14 & $(0.02) * * *$ & 0.16 & $(0.02)^{* * *}$ & - & & 0.15 & $(0.01)^{* * *}$ & 0.19 & $(0.01)^{* * *}$ \\
\hline$U R B_{c} \times M O N_{k c}$ & - & & -0.10 & $(0.21)$ & -0.33 & $(0.23)$ & - & & -0.06 & $(0.10)$ & 0.07 & $(0.10)$ \\
\hline$U R B_{c} \times U P_{k c}$ & - & & -0.67 & $(0.04)^{* * *}$ & -0.87 & $(0.08)^{* * *}$ & - & & -1.27 & $(0.02)^{* * *}$ & -1.84 & $(0.04)^{* * *}$ \\
\hline$U R B_{c} \times D O W N_{k c}$ & - & & -0.39 & $(0.03)^{* * *}$ & -0.74 & $(0.08)^{* * *}$ & - & & -0.20 & $(0.01)^{* * *}$ & -0.44 & $(0.02)^{* * *}$ \\
\hline$U R B_{c} \times C O N_{c}$ & - & & -2.89 & $(0.35) * * *$ & -1.69 & $(0.50) * * *$ & - & & -2.31 & $(0.10)^{* * *}$ & -2.27 & $(0.13) * * *$ \\
\hline$U R B_{c} \times E D U_{c}$ & - & & -0.07 & $(0.29)$ & 0.92 & $(0.55)^{*}$ & - & & 0.33 & $(0.08) * * *$ & -0.89 & $(0.15)^{* * *}$ \\
\hline$R \_A D J_{c} \times C L U_{k c}$ & - & & - & & 0.05 & $(0.03)^{*}$ & - & & - & & 0.08 & $(0.01)^{* * *}$ \\
\hline$R \_A D J_{c} \times M O N_{k c}$ & - & & - & & -0.51 & $(0.23)^{* *}$ & - & & - & & 0.10 & $(0.07)$ \\
\hline$R \_A D J_{c} \times U P_{k c}$ & - & & - & & -0.23 & $(0.09)^{* *}$ & - & & - & & -0.42 & $(0.04)^{* * *}$ \\
\hline$R \_A D J_{c} \quad \mathrm{x} D O W N_{k c}$ & - & & - & & -0.39 & $(0.08)^{* * *}$ & - & & - & & -0.27 & $(0.03) * * *$ \\
\hline$R \_A D J_{c} \quad \mathrm{x} C O N_{c}$ & - & & - & & 1.71 & $(0.50)^{* * *}$ & - & & - & & 0.62 & $(0.13) * * *$ \\
\hline$R \_A D J_{c} \quad \times E D U_{c}$ & - & & - & & 1.10 & $(0.61)^{*}$ & - & & - & & -1.33 & $(0.16)^{* * *}$ \\
\hline \# of est. / \# of counties & & & 14,1 & $15 / 199$ & & & & & 177 , & $076 / 199$ & & \\
\hline
\end{tabular}


Table 5 Robustness check: probability of sectoral employment growth in Iowa and North Carolina counties in 2000-2010

\begin{tabular}{|c|c|c|c|c|c|c|c|c|c|}
\hline $\begin{array}{l}\text { Dependent var:: whether or not } \\
\text { employment in industry } k \text { in a county } c \\
\text { increases between } 2000 \text { and } 2010\end{array}$ & & (1) & & & (2) & & & (3) & \\
\hline$C L U_{k c}$ & -0.39 & $(0.02)^{* * *}$ & {$[-0.16]$} & -0.35 & $(0.02)^{* * *}$ & {$[-0.15]$} & -0.32 & $(0.03)^{* * *}$ & {$[-0.15]$} \\
\hline$M O N_{k c}$ & -1.60 & $(0.04)^{* * *}$ & $\{-0.73\}$ & -1.65 & $(0.04)^{* * *}$ & $\{-0.75\}$ & -1.69 & $(0.06)^{* * *}$ & $\{-1.03\}$ \\
\hline$U P_{k c}$ & -0.03 & $(0.03)$ & {$[-0.01]$} & 0.04 & $(0.08)$ & {$[0.01]$} & 0.06 & $(0.12)$ & {$[0.01]$} \\
\hline$D O W N_{k c}$ & 0.00 & $(0.03)$ & {$[0.00]$} & 0.05 & $(0.07)$ & {$[0.01]$} & 0.05 & $(0.12)$ & {$[0.01]$} \\
\hline$C O N_{c}$ & -0.54 & $(0.21)^{* * *}$ & {$[-0.06]$} & -0.44 & $(0.23) *$ & {$[-0.05]$} & -0.71 & $(0.36)^{* *}$ & {$[-0.10]$} \\
\hline$E D U_{c}$ & 0.39 & $(0.28)$ & {$[0.04]$} & 0.49 & $(0.40)$ & {$[0.05]$} & 0.15 & $(0.60)$ & {$[0.02]$} \\
\hline$U R B_{c} \times C L U_{k c}$ & - & & & -0.17 & $(0.05)^{* * *}$ & {$[-0.02]$} & -0.20 & $(0.05)^{* * *}$ & {$[-0.03]$} \\
\hline$U R B_{c} \times M O N_{k c}$ & - & & & 0.40 & $(0.11)^{* * *}$ & $\{0.03\}$ & 0.44 & $(0.11)^{* * *}$ & $\{0.05\}$ \\
\hline$U R B_{c} \times U P_{k c}$ & - & & & -0.07 & $(0.09)$ & {$[-0.01]$} & -0.08 & $(0.13)$ & {$[-0.01]$} \\
\hline$U R B_{c} \times D O W N_{k c}$ & - & & & -0.04 & $(0.08)$ & {$[0.00]$} & -0.04 & $(0.13)$ & {$[0.00]$} \\
\hline$U R B_{c} \times C O N_{c}$ & - & & & -0.40 & $(0.54)$ & {$[-0.01]$} & -0.13 & $(0.61)$ & {$[0.00]$} \\
\hline$U R B_{c} \times E D U_{c}$ & - & & & -0.30 & $(0.52)$ & {$[-0.01]$} & 0.03 & $(0.69)$ & {$[0.00]$} \\
\hline$R \_A D J_{c} \times C L U_{k c}$ & - & & & - & & & -0.07 & $(0.04)$ & {$[-0.01]$} \\
\hline$R \_A D J_{c} \times M O N_{k c}$ & - & & & - & & & 0.07 & $(0.09)$ & $\{0.02\}$ \\
\hline$R \_A D J_{c} \times U P_{k c}$ & - & & & - & & & -0.01 & $(0.16)$ & {$[0.00]$} \\
\hline$R \_A D J_{c} \quad \mathrm{x} D O W N_{k c}$ & - & & & - & & & 0.01 & $(0.15)$ & {$[0.00]$} \\
\hline$R \_A D J_{c} \times C O N_{c}$ & - & & & - & & & 0.47 & $(0.45)$ & {$[0.03]$} \\
\hline$R A D J_{c} \times E D U_{c}$ & - & & & - & & & 0.53 & $(0.73)$ & {$[0.02]$} \\
\hline \# of industry-county pairs & \multicolumn{3}{|c|}{21,890} & \multicolumn{3}{|c|}{21,890} & \multicolumn{3}{|c|}{21,890} \\
\hline
\end{tabular}


Table 6 Effects of agglomeration economies on commuting in 2006-2010

\begin{tabular}{|c|c|c|c|c|c|c|}
\hline \multirow{2}{*}{$\begin{array}{l}\text { Dependent var.: Choice } \\
\text { of county for work } \\
A E_{d} / A E_{h}\end{array}$} & $\begin{array}{l}\text { All workers } \\
\text { (1) }\end{array}$ & (2) & \multicolumn{2}{|c|}{$\begin{array}{l}\text { Workers living in urban counties } \\
\text { (3) }\end{array}$} & \multicolumn{2}{|c|}{$\begin{array}{l}\text { Workers living in rural counties } \\
\text { (5) }\end{array}$} \\
\hline & $\begin{array}{l}0.27(<0.01)^{* * *} \\
{[0.27]}\end{array}$ & $\begin{array}{l}0.21(<0.01)^{* * *} \\
{[0.21]}\end{array}$ & $\begin{array}{l}0.26(<0.01)^{* * * *} \\
{[0.27]}\end{array}$ & $\begin{array}{l}0.14(<0.01)^{* * *} \\
{[0.14]}\end{array}$ & $\begin{array}{l}0.59(<0.01)^{* * *} \\
{[0.52]}\end{array}$ & $\begin{array}{l}0.47(<0.01)^{* * *} \\
{[0.42]}\end{array}$ \\
\hline Distance & $\begin{array}{l}-0.12(<0.01)^{* * *} \\
{[-7.65]}\end{array}$ & $\begin{array}{l}-0.13(<0.01)^{* * *} \\
{[-7.78]}\end{array}$ & $\begin{array}{l}-0.12(<0.01)^{* * *} \\
{[-7.62]}\end{array}$ & $\begin{array}{l}-0.13(<0.01)^{* * *} \\
{[-7.85]}\end{array}$ & $\begin{array}{l}-0.13(<0.01)^{* * *} \\
{[-7.83]}\end{array}$ & $\begin{array}{l}-0.13(<0.01)^{* * *} \\
{[-7.84]}\end{array}$ \\
\hline $\operatorname{Urban}(=1)$ & $\begin{array}{l}1.32(<0.01)^{* * *} \\
\{1.99\}\end{array}$ & $\begin{array}{l}1.09(<0.01)^{* * * *} \\
\{1.48\}\end{array}$ & $\begin{array}{l}1.29(<0.01)^{* * *} \\
\{1.88\}\end{array}$ & $\begin{array}{l}0.90(<0.01)^{* * *} \\
\{1.11\}\end{array}$ & $\begin{array}{l}1.39(<0.01)^{* * *} \\
\{2.26\}\end{array}$ & $\begin{array}{l}1.28(<0.01)^{* * *} \\
\{1.99\}\end{array}$ \\
\hline Firm $_{d} /$ Firm $_{h}$ & - & $\begin{array}{l}0.06(<0.01)^{* * * *} \\
{[0.06]}\end{array}$ & & $\begin{array}{l}0.14(<0.01)^{* * *} \\
{[0.07]}\end{array}$ & - & $\begin{array}{l}0.02(<0.01)^{* * *} \\
{[0.05]}\end{array}$ \\
\hline \# of obs. & \multicolumn{2}{|c|}{$5,224,042$} & \multicolumn{2}{|c|}{$3,351,099$} & \multicolumn{2}{|c|}{$1,872,943$} \\
\hline
\end{tabular}

Notes: Estimates from the conditional logit are reported. Standard errors are in parentheses. Elasticities or proportional changes in choice probability are in brackets. $* * *$ : significant at $1 \%, * *$ : significant at $5 \%, *$ : significant at $10 \%$. Commuters choose one out of counties within 100 miles from their home county. We do not consider cross-state commuting due to data availability. 